\title{
Nitrogen efficiency of eastern Canadian dairy herds: Effect on production performance and farm profitability
}

\author{
L. Fadul-Pacheco, ${ }^{*}$ D. Pellerin, ${ }^{*}$ P. Y. Chouinard, ${ }^{*}$ M. A. Wattiaux, † M. Duplessis, $\ddagger$ and É. Charbonneau* \\ *Département des Sciences Animales, Université Laval, Québec, QC, Canada G1V 0A6 \\ †Department of Dairy Science, University of Wisconsin, Madison 53706 \\ $\ddagger$ Valacta, Dairy Production Centre of Expertise Québec-Atlantic, Sainte-Anne-de-Bellevue, QC, Canada H9X 3R4
}

\begin{abstract}
Nitrogen efficiency (milk N/dietary N; NE) can be used as a tool for the nutritional, economic, and environmental management of dairy farms. The aim of this study was to identify the characteristics of herds with varying $\mathrm{NE}$ and assess the effect on farm profitability. One hundred dairy herds located in Québec, Canada, comprising on average $42 \pm 18$ cows in lactation were visited from October 2014 to June 2015. Feed intake was measured over $24 \mathrm{~h}$. Samples of each feedstuff were taken and sent to a commercial laboratory for analysis of chemical composition. Feeding management and feed prices were recorded. Milk yield was recorded and milk samples were collected over 2 consecutive milkings. Fat, protein, and milk urea $\mathrm{N}$ were analyzed. Balances of metabolizable protein (MP; MP supply - MP requirements) and rumen degradable protein (RDP; RDP supply - RDP requirement) were calculated. A hierarchical cluster analysis was conducted and allowed grouping the farms by their NE. Four clusters were identified with an average NE of 22.1 (NE22), 26.9 (NE27), 30.0 (NE30), and $35.8 \%$ (NE36). Herds in clusters NE30 and NE36 were fed diets with greater concentrations of starch, net energy for lactation, and nonfiber carbohydrates than those in the other 2 clusters. Moreover, the average proportion of corn silage was lower for herds in cluster NE22 compared with NE30 and NE36 (8.23 vs. 31.8 and $31.3 \%$ of total forages, respectively). In addition, crude protein of the diets declined from an average of 16.0 to $14.9 \%$ with increasing NE among clusters. Average dry matter intake declined from 26.1 to 22.5 $\mathrm{kg} / \mathrm{d}$ as NE of clusters increased. Herds in cluster NE22 had lower yields of milk (28.7 vs. $31.8 \mathrm{~kg} / \mathrm{d})$, fat $(1.15$ vs. $1.29 \mathrm{~kg} / \mathrm{d}$ ), and protein (0.94 vs. $1.05 \mathrm{~kg} / \mathrm{d}$ ) than the other clusters. Also, milk urea $\mathrm{N}$ was greater for farms in cluster NE22 $(13.2 \mathrm{mg} / \mathrm{dL})$ than for farms in the other clusters $(11.4 \mathrm{mg} / \mathrm{dL})$. Furthermore, MP and
\end{abstract}

Received July 27, 2016.

Accepted April 22, 2017.

${ }^{1}$ Corresponding author: edith.charbonneau@fsaa.ulaval.ca
RDP balances decreased from 263.2 to $-153.7 \mathrm{~g} / \mathrm{d}$ and from 594.7 to $486.9 \mathrm{~g} / \mathrm{d}$, respectively, with increasing $\mathrm{NE}$ among clusters. Income over feed cost increased from $\$ 14.3$ to $\$ 17.3 /$ cow per day (Can $\$$ ) as NE among clusters augmented. Results from this study showed that some farms were able to achieve high NE by using lower levels of dietary $\mathrm{N}$ and having cows with lower DMI while maintaining milk performance. These farms had a potentially lower environmental impact, and they were more profitable.

Key words: nitrogen efficiency, commercial dairy farm, cluster analysis, income over feed cost

\section{INTRODUCTION}

Nitrogen excretion is directly related to $\mathrm{N}$ intake (Rotz, 2004). Studies have shown that diets with different concentrations of $\mathrm{CP}$ had similar excretions of fecal $\mathrm{N}$ but differed in urea $\mathrm{N}$ excretion (Colmenero and Broderick, 2006a; Edouard et al., 2016). Urea is the main $\mathrm{N}$ component in urine (i.e., 50-90\%) and has the highest potential for $\mathrm{N}$ volatilization (Bussink and Oenema, 1998). Therefore, reducing $\mathrm{N}$ intake is the major strategy to reduce $\mathrm{N}$ excretion and counteract $\mathrm{N}$ pollution (Dijkstra et al., 2011; Hristov et al., 2011). Thus, N management is an important challenge in reducing environmental pollution without impairing animal performance. Nitrogen efficiency (NE; milk N secretion/dietary $\mathrm{N}$ intake) can be used as a tool for environmental and feeding management in dairy herds. In addition, it was suggested that improving NE may also enhance farm profits (Powell et al., 2010), which is advantageous for the producers.

Nitrogen efficiency has been shown to be lower under commercial conditions than under experimental conditions (Powell et al., 2010), suggesting that improvement in feeding practices can be achieved. In commercial settings, NE was around $25 \%$ and ranged between 17 and 35\% (Jonker et al., 2002a; Powell et al., 2006; Gourley et al., 2012), whereas under experimentally controlled conditions mean NE was 30\% and ranged between 18 and 42\% (Hristov et al., 2004; Huhtanen 
and Hristov, 2009; Phuong et al., 2013). The principal dietary factor affecting NE is dietary $\mathrm{CP}$ concentration (Huhtanen and Hristov, 2009), where an increase in CP will negatively affect NE. Colmenero and Broderick (2006b) reported a reduction of 5.4 percentage units in $\mathrm{NE}$ by increasing $\mathrm{CP}$ in the diet from 16.5 to $19.4 \%$. Another study also reported a reduction of NE from 27 to $24 \%$ by increasing $\mathrm{CP}$ in the diet from 16.7 to $18.4 \%$ (Broderick, 2003). In these studies, the modifications in dietary $\mathrm{CP}$ concentration did not affect milk production or the yields of milk fat and protein.

Another strategy to improve NE is to enhance animal performance by increasing dietary energy (Broderick, 2003; Rotz, 2004). In this regard, a major challenge of feeding protein, as shown by Rotz (2004) using a whole-farm modeling approach, is to provide the right amount with the proper degradation characteristics and to supply enough available energy to maximize animal performance while reducing $\mathrm{N}$ excretion at minimum cost. Therefore, we hypothesized that dairy herds could be characterized by their NE and that differences in animal performance and feeding strategies would exist among groups. Thus, the objective of this study was to identify the characteristics of commercial lactating herds with varying $\mathrm{NE}$ and assess its effect on farm profitability.

\section{MATERIALS AND METHODS}

\section{Data Collection}

All experimental procedures of this study were approved by the Animal Care Committee from Université Laval, Québec, Canada, following the guidelines of the Canadian Council on Animal Care (1993). One hundred dairy farms located in the province of Québec, Canada, were recruited. To be eligible for participation, farms had to be enrolled with the milking recording system of Valacta (Dairy Production Centre of Expertise, Québec and Atlantic Provinces, Sainte-Anne-de-Bellevue, QC, Canada). Herds comprised Holstein cows. Producers were contacted by phone, and their participation was voluntary. Herd size ranged from 16 to 113 cows in lactation. Among them, 98 herds were housed in tiestall barns, whereas the remaining 2 herds were kept in freestalls. All cows were milked twice a day. Farms were visited once at the times of feeding and milking to cover a production period of $24 \mathrm{~h}$. The visit to each of the 100 herds was scheduled to coincide with a regular monthly DHI test and was completed between October 2014 and June 2015.

In the first morning of the visit, orts were discarded. Feeds offered (Table 1) were weighed and sampled for cows in lactation. When the farm feeding system was
TMR, feeds offered were measured per group. When the farm feeding system was manual component feeding (MCF) or component feeding with an automatic feeding system (AFS), forages offered were measured per group, but concentrate feeds offered for each cow were measured individually. When forages were fed as bales of silage or hay, bales were weighed with an electronic scale (OCSB3 Compact Crane Scale, Anyload Transducer Co. Ltd., Burnaby, BC, Canada). For concentrate feeds, if they were fed manually, the quantities were weighed before they were offered to the cows. When an AFS was used on the farm, the quantities of feeds offered were recorded as programmed in the system. To ensure the accuracy of AFS measurements, a validation was performed by weighing once the amounts of feeds served, which were compared with the programmed quantity. When feeds were fed as TMR, the quantities offered were recorded from the scale of the mixing system. The amount of TMR offered to at least 10 cows was weighed for validation. Orts were weighed and sampled per group before or after the a.m. milking of the second day according to individual feeding management practices.

Samples of all individual dietary ingredients and TMR were taken and frozen at $-20^{\circ} \mathrm{C}$. Additional silage samples were taken and sent to the Valacta laboratory for determination of $\mathrm{pH}, \mathrm{NH}_{3}-\mathrm{N}$, and organic acid profile by near-infrared spectroscopy.

The feedstuff samples were oven dried at $55^{\circ} \mathrm{C}$ for 48 $\mathrm{h}$ to determine DM, ground through a 1-mm sieve, and analyzed for nutrient composition by wet chemistry in a commercial laboratory (SGS Agrifood Laboratories, Guelph, ON, Canada) according to the following methods: $\mathrm{CP}(\mathrm{N} \times 6.25$; method 990.03; AOAC International, 2005), soluble protein (Roe et al., 1990), ADF [Ankom, 2017b; solutions as in method 973.18; AOAC International, 2005], NDF [Ankom, 2017c; solutions as in Van Soest et al. (1991) with the inclusion of heatstable $\alpha$-amylase], acid detergent insoluble $\mathrm{CP}$ and neutral detergent insoluble CP (method 990.03; AOAC International, 2005), lignin (method 973.18D; AOAC International, 2000), crude fat (Ankom, 2009; AOCS, 2008), and starch (method 996.11; AOAC International, 2005). The NDF of orts were analyzed using the Ankom filter bag technique (Ankom, 2017a; solutions as in Van Soest et al., 1991).

During the p.m. and next a.m. milkings, milk yield from each cow was recorded and milk was sampled using inline milk meters. Samples were stored at $4^{\circ} \mathrm{C}$ with a preservative (2-bromo-2-nitropan-1,3-diol) and sent to the Valacta laboratory for analyses of fat, CP, lactose, MUN, SCC, and BHB. Analyses were performed using a Foss MilkoScan FT 6000 for infrared evaluation of milk components combined with a Fossomatic FC for 
SCC analysis (Foss Electric A/S, Hillerød, Denmark). The calibrations for BHB infrared analyses were developed with a continuous flow analyzer $\mathrm{San}^{++} \mathrm{Au}-$ tomated Wet Chemistry Analyzer, Skalar, Breda, the Netherlands) as described by Denis-Robichaud et al. (2014) and de Roos et al. (2007).

The BW of all lactating cows was estimated from heart girth circumference according to Yan et al. (2009) in the morning of the first day. Data for DIM, parity, and genetic parameters were obtained from Valacta. A data logger (Hobo U23 Pro v2, Onset Computer Corporation, Bourne, MA) was installed in the barn to measure the ambient temperature and the relative humidity every 10 min during the visit. Feeding system, numbers and frequency of feeding, milking intervals, health problems, and price of feedstuffs were noted when applicable.

\section{Calculations}

For each dietary group within a farm, average DMI per cow was calculated as [feed offered $(\mathrm{kg} / \mathrm{d})$ - orts $(\mathrm{kg} / \mathrm{d})] /$ number of cows per group. The DMI per cow was then averaged by herd. To account for feed sorting, the proportions of concentrate in orts were estimated using the average NDF of forages and concentrate offered compared with NDF of orts. Using these values, it was possible to estimate the proportion of DMI com- ing from forages and from concentrate for MCF and AFS herds to correctly adjust the nutrient composition of the diet from the chemical analysis obtained. Diet composition was then calculated using the results of chemical analyzes and the averaged amount eaten per cow for each feed using the SQL procedure of SAS (SAS Institute Inc., 2011), and it was then averaged by herd. Daily milk yield per cow was averaged by herd. Milk composition was also averaged by herd proportionally to cow milk production.

Nitrogen efficiency was defined as the percentage of intake $\mathrm{N}$ that is converted in $\mathrm{N}$ in milk and was calculated as $100 \times$ milk N secretion/dietary N intake, assuming that milk protein contains $6.38 \% \mathrm{~N}$ (DePeters and Ferguson, 1992; NRC, 2001). Milk energy concentration $(\mathrm{Mcal} / \mathrm{kg})$ was calculated as $[0.0929 \times$ fat $(\%)]$ $+[0.0547 \times$ protein $(\%) / 0.93]+[0.0395 \times$ lactose $(\%)]$ according to NRC (2001). Energy efficiency of the cow was calculated as $100 \times$ [milk energy concentration $(\mathrm{Mcal} / \mathrm{kg}) \times$ milk yield $(\mathrm{kg} / \mathrm{d})] /\left[\right.$ dietary $\mathrm{NE}_{\mathrm{L}}(\mathrm{Mcal} /$ $\mathrm{kg}) \times \mathrm{DMI}(\mathrm{kg} / \mathrm{d})]$, where dietary $\mathrm{NE}_{\mathrm{L}}$ was calculated as suggested by NRC (2001). Fat-corrected milk (4\%) was calculated as $0.4 \times$ milk yield $(\mathrm{kg} / \mathrm{d})+15 \times$ fat yield (kg/d; Gaines, 1928; NRC, 2001). Feed efficiency was calculated as FCM $(\mathrm{kg} / \mathrm{d}) /$ feed intake $(\mathrm{kg} / \mathrm{d})$. The MUN:milk protein ratio was calculated as MUN yield $(\mathrm{mg} / \mathrm{d}) /$ milk protein yield $(\mathrm{g} / \mathrm{d}$; Wattiaux and Crump, 2014). In addition, predicted MP and RDP balances

Table 1. Main ingredients used for 100 dairy herds of the province of Québec divided into 4 clusters ${ }^{1}$ according to their nitrogen efficiency

\begin{tabular}{|c|c|c|c|c|c|c|c|c|}
\hline Item & $\mathrm{n}$ & Mean $\pm \mathrm{SD}^{2}$ & $\mathrm{n}$ & Mean \pm SD & $\mathrm{n}$ & Mean $\pm \mathrm{SD}$ & $\mathrm{n}$ & Mean \pm SD \\
\hline High-moisture corn & 1 & 13.7 & 3 & $17.3 \pm 6.4$ & 7 & $18.9 \pm 2.9$ & 4 & $24.4 \pm 10.5$ \\
\hline Cracked corn & 2 & $22.7 \pm 3.4$ & 6 & $11.4 \pm 6.8$ & 5 & $15.8 \pm 11.0$ & 4 & $18.0 \pm 8.4$ \\
\hline Ground corn & 10 & $14.3 \pm 7.2$ & 11 & $17.6 \pm 6.9$ & 13 & $19.0 \pm 7.1$ & 5 & $22.9 \pm 10.4$ \\
\hline Barley & 3 & $9.3 \pm 0.8$ & 4 & $15.6 \pm 6.6$ & 2 & $13.2 \pm 9.2$ & 1 & 14 \\
\hline \multicolumn{9}{|l|}{ Protein source, \% of DM } \\
\hline Soybean meal & 4 & $8.3 \pm 4.9$ & 7 & $6.6 \pm 2.7$ & 10 & $8.0 \pm 3.2$ & 6 & $8.0 \pm 4.4$ \\
\hline Full-fat soybean & 1 & 5.3 & 2 & $3.6 \pm 0.7$ & 1 & 9.7 & - & - \\
\hline Other protein sources ${ }^{4}$ & $-^{5}$ & - & - & - & 3 & $4.6 \pm 1.5$ & - & - \\
\hline Commercial supplements & 13 & $9.6 \pm 8.8$ & 21 & $7.4 \pm 5.2$ & 23 & $6.9 \pm 3.4$ & 12 & $8.3 \pm 4.6$ \\
\hline Fat supplements, \% of DM & 2 & $0.95 \pm 0.37$ & 5 & $0.77 \pm 0.35$ & 9 & $1.10 \pm 0.44$ & 7 & $1.11 \pm 0.56$ \\
\hline \multicolumn{9}{|l|}{ Forages, $\%$ of DM } \\
\hline
\end{tabular}

${ }^{1}$ Herds were divided into clusters according to their nitrogen efficiency (NE), calculated as $100 \times$ milk $\mathrm{N}$ secretion/dietary $\mathrm{N}$ intake. NE22 $=$ $22.1 \pm 1.88 \%(\mathrm{n}=20) ; \mathrm{NE} 27=26.9 \pm 0.99 \%(\mathrm{n}=31) ; \mathrm{NE} 30=30.0 \pm 0.96 \%(\mathrm{n}=31) ; \operatorname{NE} 36=35.8 \pm 2.76 \%(\mathrm{n}=18)$.

${ }^{2}$ Mean \pm SD of herds using the feed.

${ }^{3}$ Oats, wheat, or mixed cereals.

${ }^{4}$ Cottonseeds, canola meal, distillers grains, or corn gluten meal.

${ }^{5}$ Ingredient not used on farms of specific clusters. 
(supply - requirements) and DMI were calculated according to NRC (2001). Ambient barn temperature and relative humidity were averaged by herd and were used to calculate the temperature-humidity index according to Kendall et al. (2008).

Total feed cost per farm for lactating cows was calculated by adding the cost of purchased ingredients to the cost of production of homegrown cereals, pulses, oilseeds, and forages. The actual price paid by each farmer for purchased feeds was recorded. For the homegrown feeds, the average provincial production cost for the year 2015 was used (Valacta, 2015; Les Producteurs de Grains du Québec, 2016). An average of milk component prices for 2015 was used to calculate milk price by farm according to its composition (Les Producteurs de Lait du Québec, 2016). Milk price was then discounted for the 2015 average deductions for hauling and marketing. Also, bonuses for low bacterial count and SCC and a bonus or penalty for nonfat solid:fat ratio according to the average for the year 2015 were calculated per farm. Income over feed cost (IOFC; Can $\$$ cow per day) was calculated for each herd as milk price $(\$ / \mathrm{kg}) \times$ milk yield $(\mathrm{kg} / \mathrm{d})-$ feed cost $(\$ /$ $\mathrm{kg}) \times$ feed intake $(\mathrm{kg} / \mathrm{d})$.

\section{Data Analysis}

Statistical analyses were performed on herd averages. Herds were grouped according to their NE using the CLUSTER procedure of SAS (SAS Institute Inc., 2011). Ward's method was used, which minimizes the withingroup sum of squares (Borcard et al., 2011). Based on pseudo T-squared, pseudo F, cubic clustering criterion, and R-squared statistics, 4 clusters were identified as the optimal number to describe the distribution of $\mathrm{NE}$ calculated for the 100 herds in this study. The 4 groups formed accounted for $88 \%$ of the variation.

To identify differential characteristics between clusters, the following variables were tested: (1) diet- and feed-related variables, including $\mathrm{CP}$, soluble $\mathrm{CP}$, RDP, RUP, MP balance, RDP balance, ADF, NDF, lignin, neutral detergent insoluble $\mathrm{CP}$, acid detergent insoluble $\mathrm{CP}, \mathrm{NFC}$, TDN, starch, fat, $\mathrm{NE}_{\mathrm{L}}$, silage fermentation profile (ammonia, lactic acid, acetic acid, butyric acid, and total VFA), IOFC, percentage of each forage type (i.e., baled silage, chopped silage, and corn silage) within the forage portion of the diet, daily feeding frequency, and farm feeding system (i.e., MCF, AFS, and TMR); (2) animal performance, including BW; DMI; yields of milk, FCM, fat, protein, and lactose; concentrations of milk fat, protein, lactose, urea N, BHB, and energy; MUN:milk protein ratio; energy efficiency; feed efficiency; and difference between predicted and actual DMI; and (3) animal-dependent variables, including
DIM and EBV for milk yield as well as milk protein concentration and yield. Percentages of forage type within the forage portion of the diet were transformed (arcsine square root) to meet homogeneity of variance criteria. Differences among clusters for these variables were analyzed using the GLIMMIX procedure of SAS (SAS Institute Inc., 2011) with the Tukey-Kramer adjustment for multiple comparisons. Pearson correlations were performed between NE and milk yield, milk protein concentration, DMI, dietary CP concentration, and energy efficiency using the CORR procedure of SAS. Differences between clusters were declared significant when $P$-values were $\leq 0.05$, and tendencies were noted when $0.05<P<0.10$.

\section{RESULTS AND DISCUSSION}

The number of cows in lactation per herd was (average $\pm \mathrm{SD}) 42.3 \pm 18.0$, ranging from 16 to 113 cows. The provincial average for herd size followed by the DHI agency was 60.7 , among which $87.4 \%$ of cows were in lactation (Valacta, 2016). The cluster analysis classified the 100 herds into 4 distinct groups according to their NE. The less efficient group had an NE of 22.1 $\pm 1.88 \%$ (NE22). The 20 farms in this cluster had, on average, 32 cows in lactation. Among them, 11 farms used AFS, 7 farms used MCF, and 2 farms used TMR. The next cluster had an NE of $26.9 \pm 0.99 \%$ (NE27) and comprised 31 farms with an average of 41 cows in lactation. Among them, 19 farms used AFS, 7 farms used TMR, and 5 farms used MCF. The third cluster had an NE of $30.0 \pm 0.96 \%$ (NE30). This cluster comprised 31 farms with an average herd size of 49 cows in lactation. Their feeding system was predominantly TMR (15 farms) and AFS (13 farms), whereas the remaining 3 farms used MCF. The highest NE was 35.8 $\pm 2.76 \%$ (NE36); this cluster comprised 18 farms, with an average of 47 cows in lactation. The type of feeding system was evenly distributed, with 5 farms using MCF, 6 farms using AFS, and 7 farms using TMR. The NE was different between each cluster $(P<0.001)$. There was a tendency for a difference in the occurrence of different feeding systems among clusters $(P=0.06$; data not shown), and there was no difference in the feeding frequency $(3.7 \pm 1.4$ daily feed distributions, $P$ $=0.14$; data not shown).

In this study, the average NE was $29 \%$ and ranged from 19 to $40 \%$ among farms. Other studies under commercial conditions, representing a broad range of management practices in different countries, reported NE between 15 and 35\% (Arriaga et al., 2009; Gourley et al., 2012). This great variability in NE among commercial herds observed in the current study was also reported by Powell et al. (2010). It confirmed the 
Table 2. Average milk and component yields, FCM, and milk composition for 100 dairy herds of the province of Québec divided into 4 clusters according to their nitrogen efficiency

\begin{tabular}{|c|c|c|c|c|c|c|}
\hline \multirow[b]{2}{*}{ Item } & \multicolumn{4}{|c|}{ Cluster $^{1}$} & \multirow[b]{2}{*}{ SEM } & \multirow[b]{2}{*}{$P$-value } \\
\hline & NE22 & NE27 & NE30 & NE36 & & \\
\hline \multicolumn{7}{|l|}{ Yield, kg/d } \\
\hline Milk & $28.7^{\mathrm{b}}$ & $31.1^{\mathrm{a}}$ & $31.9^{\mathrm{a}}$ & $32.5^{\mathrm{a}}$ & 0.82 & $<0.01$ \\
\hline Fat & $1.15^{\mathrm{b}}$ & $1.25^{\mathrm{a}}$ & $1.28^{\mathrm{a}}$ & $1.32^{\mathrm{a}}$ & 0.03 & $<0.01$ \\
\hline Protein & $0.94^{\mathrm{b}}$ & $1.02^{\mathrm{a}}$ & $1.05^{\mathrm{a}}$ & $1.07^{\mathrm{a}}$ & 0.03 & $<0.01$ \\
\hline Lactose & $1.31^{\mathrm{b}}$ & $1.44^{\mathrm{a}}$ & $1.46^{\mathrm{a}}$ & $1.49^{\mathrm{a}}$ & 0.04 & $<0.01$ \\
\hline $\mathrm{FCM}^{2}$ & $28.8^{\mathrm{b}}$ & $31.3^{\mathrm{ab}}$ & $32.0^{\mathrm{a}}$ & $32.9^{\mathrm{a}}$ & 0.81 & $<0.01$ \\
\hline \multicolumn{7}{|l|}{ Milk composition } \\
\hline Fat, $\%$ & 4.02 & 3.98 & 4.03 & 4.07 & 0.05 & 0.49 \\
\hline Protein, \% & $3.27^{\mathrm{yz}}$ & $3.24^{\mathrm{y}}$ & $3.31^{\mathrm{z}}$ & $3.28^{\mathrm{yz}}$ & 0.02 & 0.06 \\
\hline Lactose, $\%$ & 4.57 & 4.58 & 4.58 & 4.58 & 0.01 & 0.85 \\
\hline $\mathrm{BHB}, \mu \mathrm{mol} / \mathrm{L}$ & 69 & 73 & 74 & 77 & 4.3 & 0.54 \\
\hline Energy, ${ }^{3}$ Mcal of $\mathrm{NE}_{\mathrm{L}} / \mathrm{kg}$ & 0.71 & 0.73 & 0.71 & 0.72 & 0.005 & 0.31 \\
\hline MUN, mg/dL & $13.2^{\mathrm{a}}$ & $11.4^{\mathrm{b}}$ & $11.8^{\mathrm{ab}}$ & $11.1^{\mathrm{b}}$ & 0.52 & 0.02 \\
\hline MUN:milk protein ${ }^{4}$ & $4.03^{\mathrm{a}}$ & $3.52^{\mathrm{b}}$ & $3.57^{\mathrm{ab}}$ & $3.38^{\mathrm{b}}$ & 0.16 & 0.02 \\
\hline \multicolumn{7}{|c|}{$\overline{\mathrm{a}, \mathrm{b}}$ Means within a row with different superscripts differ $(P \leq 0.05)$. } \\
\hline \multicolumn{7}{|c|}{${ }^{\mathrm{y}, \mathrm{z}}$ Means within a row with different superscripts tend to differ $(0.05<P<0.10)$} \\
\hline \multicolumn{7}{|c|}{$\begin{array}{l}{ }^{1} \text { Herds were divided into clusters according to their nitrogen efficiency }(\mathrm{NE}) \text {, calculated as } 100 \times \text { milk N secre } \\
\text { tion/dietary N intake. NE22 }=22.1 \pm 1.88 \%(\mathrm{n}=20) ; \mathrm{NE} 27=26.9 \pm 0.99 \%(\mathrm{n}=31) ; \mathrm{NE} 30=30.0 \pm 0.96 \% \\
(\mathrm{n}=31) ; \mathrm{NE} 36=35.8 \pm 2.76 \%(\mathrm{n}=18)\end{array}$} \\
\hline \multicolumn{7}{|c|}{${ }^{2}$ Calculated as $0.4 \times$ milk yield $(\mathrm{kg} / \mathrm{d})+15 \times$ fat yield $(\mathrm{kg} / \mathrm{d})$ (Gaines, 1928$)$} \\
\hline \multicolumn{7}{|c|}{${ }^{3}$ Calculated as $[0.0929 \times$ fat $(\%)]+[0.0547 \times$ protein $(\%) / 0.93]+[0.0395 \times$ lactose $(\%)](\mathrm{NRC}, 2001)$} \\
\hline
\end{tabular}

potential for improving the NE of several commercial dairy herds.

The yields of milk, FCM, fat, protein, and lactose were lower $(P<0.01)$ for the NE22 cluster than for the others clusters (Table 2). There was a tendency for greater protein concentration in the milk produced by herds in NE30 than in the milk produced by herds in NE27, whereas intermediate values were observed for clusters NE22 and NE36. However, fat, lactose, and BHB concentrations in milk did not differ among clusters.

Milk urea $\mathrm{N}$ was greatest in NE22, intermediate in NE30, and lower in the NE27 and NE36 clusters (Table $2)$. The same pattern was seen for the MUN:milk protein ratio. This latter ratio was proposed as an indicator of NE and of the adequacy of protein supply to maximize milk protein and minimize urinary urea $\mathrm{N}$ (Wattiaux and Crump, 2014). Although differences in MUN and in MUN:milk protein ratio (Table 2) were observed among clusters, these indicators did not perfectly reflect NE or dietary CP (Table 3). Arriaga et al. (2009) reported that bulk tank MUN was not an accurate estimator for NE in commercial settings. Under experimental conditions, MUN has been highly associated with NE and dietary CP level (Broderick and Clayton, 1997; Nousiainen et al., 2004), although it also can be influenced by NFC concentration (Hristov and Ropp, 2003). Using MUN as a monitoring tool was proven successful when attempting to reduce excess dietary
$\mathrm{CP}$ in commercial farms (Jonker et al., 2002b). However, due to variations in MUN related to cow-related characteristics (Huhtanen et al., 2015), management factors (Wattiaux et al., 2005), and possibly genetics (Aguilar et al., 2012), industry standards are likely to be replaced with farm-specific target MUN values in the future. In our study, the lack of perfect agreement between MUN and NE (Table 2) and between MUN and dietary CP (Table 3 ) may have been attributable in part to the small difference in NE between the 2 intermediate groups (NE27 and NE30). Further studies are needed before using MUN concentrations or related variables such as MUN:milk protein ratio as indicators of NE in commercial situations.

The NE36 cluster had the lowest average DMI, measured over a 24 -h period, at $20.6 \mathrm{~kg} / \mathrm{d}$ (Table 3 ). There was a difference of $5.4 \mathrm{~kg} / \mathrm{d}$ in average DMI between the NE22 and NE36 clusters, whereas the NE27 and NE30 clusters had intermediary values. The average DMI for the 100 herds was $23.5 \pm 3.05 \mathrm{~kg} / \mathrm{d}$, which was similar to the average predicted DMI using the NRC (2001) formula $(23.4 \pm 1.45 \mathrm{~kg} / \mathrm{d})$. However, there was a greater variation in observed compared with predicted DMI (Table 3). This variability could be explained by the composition and physical characteristics of diets that are not taken into account in the NRC (2001) formula, which considers only animal parameters. NRC (2001) indicated that $73 \%$ of the predicted intake was within $\pm 10 \%$ of the observed intake. In our feed inges- 
tion data, $57 \%$ of the predicted intake was within $\pm 10 \%$ of the observed intake. In another study conducted on commercial farms, only 3 of the 11 herds studied had an observed voluntary feed ingestion within a range of $\pm 15 \%$ from the calculated DMI according to the NRC (2001) formula (Vallimont et al., 2010). These results point to high accuracy but low precision of the NRC (2001) formula for predicting DMI under the conditions of the current study. This analysis confirmed the importance of on-farm validation of DMI to correctly formulate diets under commercial conditions. As mentioned by Vallimont et al. (2010), measures of DMI under commercial conditions may not be as accurate as in controlled research settings on an individual cow basis, but they remain accurate when evaluated on a group basis. Because many factors may affect DMI of a cow on a given day, a group approach, as was made in this study, should be adopted to evaluate on-farm feed consumption.

Dietary CP concentrations were different among groups. Farms in the NE36 cluster had the lowest CP level (Table 3), followed by the NE30 and NE27 clusters. Finally, the NE22 cluster had the highest dietary CP concentration. Gourley et al. (2012) evaluated the NE in 2 types of commercial production systems (grazing and confinement) in the United States and Australia and reported that NE had a negative relationship with $\mathrm{N}$ intake. Other studies have also reported that the highest $\mathrm{NE}$ is generally obtained at the lowest $\mathrm{N}$ intake (Rotz, 2004; Powell et al., 2010). Our results agree with these findings. There was no difference in the RUP between clusters in our study $(5.0 \pm 0.60 \%$ of $\mathrm{DM})$, but

Table 3. Average intake, diet parameters, type of forage, RDP and MP balances, energy efficiency, and milk income over feed cost (IOFC) for 100 dairy herds of the province of Québec divided into 4 clusters according to their nitrogen efficiency

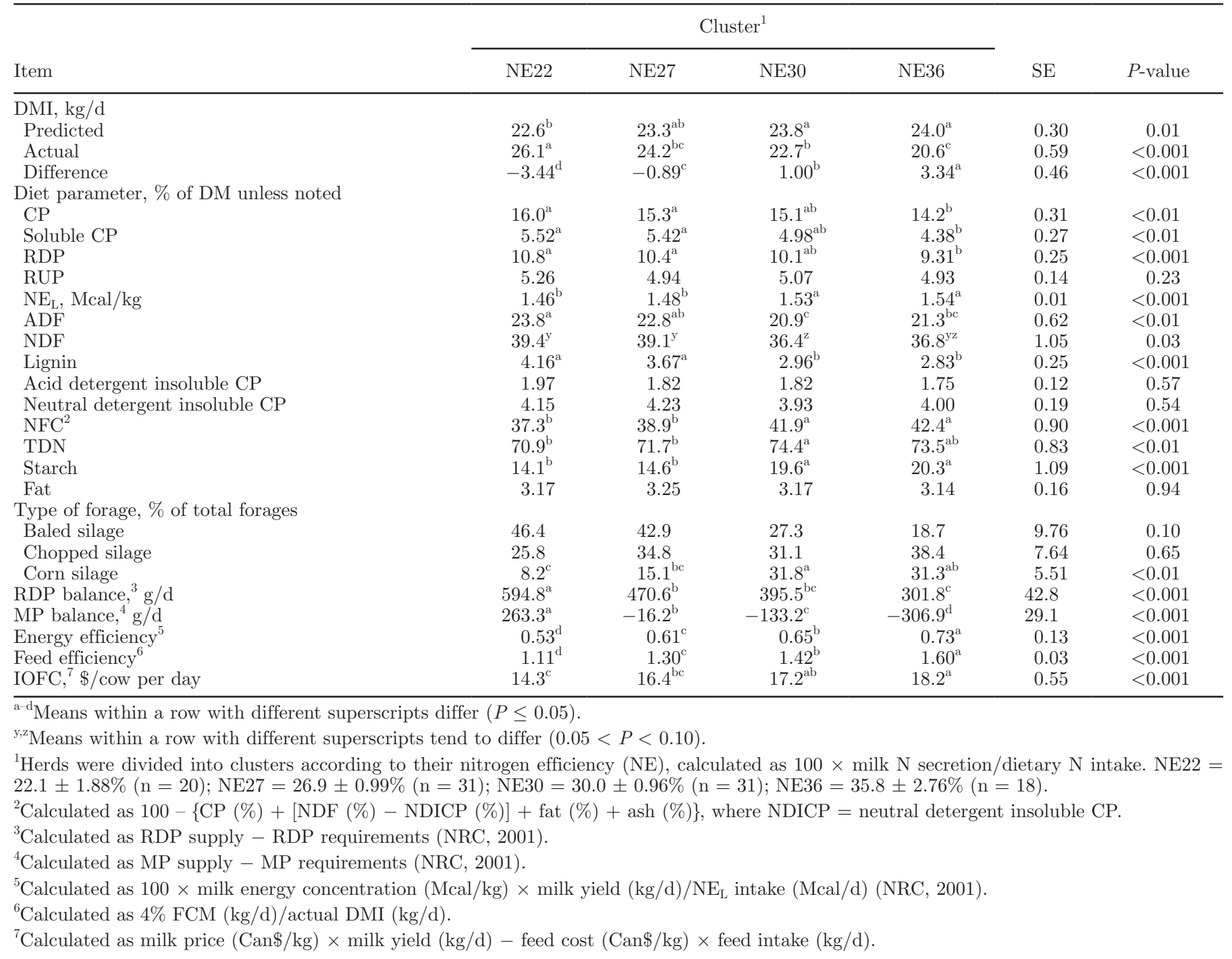


RDP and soluble CP were lower for the NE36 cluster compared with the NE22 and NE27 clusters (Table 3). Results of this study therefore reinforce the suggestion by Dijkstra et al. (2011) that a reduction in RDP can be a strategy for increasing NE.

Dietary ADF and lignin concentrations were lower for the NE30 and NE36 clusters than for the NE22 cluster (Table 3), which may be related to the main source and quality of forages used by the farms in each cluster. There was no difference in the percentage of chopped silage, although large numerical variations in the proportion of baled silage were seen (Table 3). Corn silage, as a proportion of total forages, was greater in the NE30 and NE36 clusters than in the NE22 cluster. Previous studies also reported an improvement of NE when corn silage was the main forage in the diet (Hristov et al., 2004) and when corn silage was substituted or replaced alfalfa silage (Brito and Broderick, 2006; Arndt et al., 2015).

Dietary concentrations of NFC were greater in the NE30 and NE36 clusters compared with the NE22 and NE27 clusters (Table 3). Calsamiglia et al. (2010) reported that diets containing less $\mathrm{CP}$ and more NFC resulted in greater NE, which agrees with our results. Also, because carbohydrates are the main source of energy for bacteria, they can increase ruminal microbial protein synthesis (Bach et al., 2005), which can improve NE. There were also differences in dietary starch concentration between clusters. Herds with the highest NE (i.e., NE30 and NE36) were fed diets containing more starch than herds in the 2 clusters with the lowest NE. No differences were found in the percentage of concentrate in the diet among clusters $(P=0.96)$. Therefore, variation in dietary starch concentrations could come from differences in the proportion of corn silage between clusters. Interestingly, the highest dietary starch concentration $(20.3 \% \mathrm{DM})$ was in cluster NE36. This level of starch is usually considered a low (i.e., $20 \%$ of DM; Chase, 2007) or medium (21\% of DM; Dann et al., 2014) value in dairy diets.

No differences were found in the fermentation profile of forages $(P \geq 0.43$; data not shown). Similarly, there were no differences in estimated $\mathrm{BW}$ of cows $(P=0.42)$ or in average EBV for milk yield, protein yield, or protein concentration $(P \geq 0.26$; data not shown). Finally, no differences in the temperature-humidity index were found among clusters $(P=0.30)$.

The RDP balance declined from 594.8 to $301.8 \mathrm{~g} / \mathrm{d}$ with increasing NE among clusters (Table 3). This result may suggest that there was an excess of RDP in the diets for all groups. This excess could be explained mainly by the type of forages used (Tables 1 and 3 ). For all farms, forages accounted for $71 \%$ of the ration on average (data not shown). Excess RDP are common when high amounts of baled and chopped silages are used, such as for most farms in this study. Moreover, herds in the top 2 clusters for NE (NE30 and NE36) were probably better at utilizing RDP in part because of higher amounts of NFC and starch in the diet. The MP balance was negative for the NE27, NE30, and NE36 clusters (Table 3), which could indicate that the NRC (2001) model may have overestimated the MP requirements for herds in these clusters. In addition, the MP recommendations were met only in the cluster with the lowest NE (NE22), which indicates that the capacity to correctly predict MP requirements of the NRC model was limited under the husbandry conditions of dairy herds in the current study.

Dietary concentration of $\mathrm{NE}_{\mathrm{L}}$ was greater in the NE30 and NE36 clusters compared with the NE22 and NE27 clusters (Table 3). Moreover, energy and feed efficiencies were different for all clusters and varied in the same direction as NE (Table 3). Results indicated that energy efficiency and NE of dairy herds were highly correlated $(r=0.82$; Figure 1). This relationship was expected given that the farms in clusters with superior NE had greater average milk yield and lower average DMI (Tables 2 and 3). In addition, differences between predicted and actual intake were greater for the 2 extreme clusters (Table 3). The NE22 and NE36 clusters had negative and positive differences, which means that the actual intake of cows in NE22 was greater than expected, whereas it was lower than expected for NE36 using the NRC (2001) formula. The same pattern was seen for the 2 intermediate clusters. Cows with low DMI may have a slower rate of passage of digesta, which would contribute to increasing DM digestibility (Colucci et al., 1982) and enhance nutrient utilization.

Among the 4 parameters used to calculate NE, DMI measured over a 24 -h period had the highest correlation with NE $(\mathrm{r}=-0.65 ; P<0.001)$, followed by dietary $\mathrm{CP}$ concentrations $(\mathrm{r}=-0.42 ; P<0.001)$, milk yield $(\mathrm{r}=0.31 ; P<0.01)$, and milk protein concentration $(P=0.46)$. Different factors can contribute to variations in DMI, which has a large effect on NE. Cows' BW and milk yield are the main parameters used for DMI prediction in NRC (2001). Feeding management (e.g., continuous access to feed), physical and chemical characteristics of the diets (e.g., fiber content, type of fat supplements, concentration and degradability of protein, site of starch and fiber digestion, type of forage, particle size, and silage fermentation products; Broderick, 1995; Allen, 2000), and feeding frequency (Sova et al., 2013; Hart et al., 2014) can also contribute to fluctuations in DMI. Finally, genetic variations have been reported to have an effect on cow DMI (Veerkamp and Brotherstone, 1997; Li et al., 2016). In addition, dairy cattle may differ genetically in their 


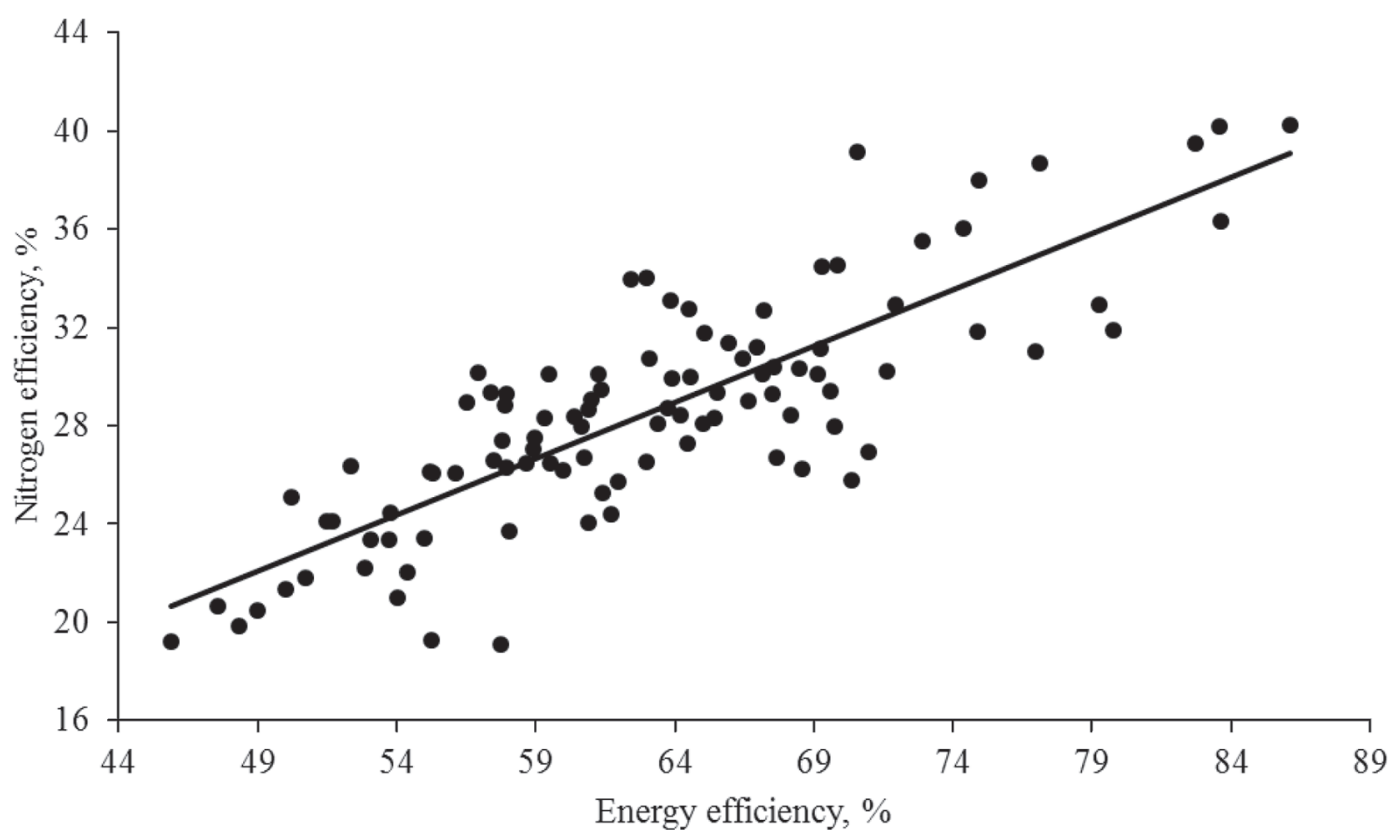

Figure 1. Relationship between nitrogen efficiency and energy efficiency of commercial dairy herds $(\mathrm{n}=100 ; \mathrm{r}=0.82)$. Nitrogen efficiency was calculated as $100 \times$ milk N secretion/dietary N intake. Energy efficiency was calculated as $100 \times$ milk energy concentration $(\mathrm{Mcal} / \mathrm{kg}) \times$ milk yield $(\mathrm{kg} / \mathrm{d}) / \mathrm{NE}_{\mathrm{L}}$ intake (Mcal/d) $(\mathrm{NRC}, 2001)$.

feed efficiency, which can be assessed by the concept of residual feed intake. Divergence between lactating animals was previously established by Connor et al. (2013). Although some of these factors were evaluated in this study, more investigations are needed to better understand why the NRC equation is correctly predicting DMI in some herds, such as those in clusters NE27 and NE30, but is overpredicting (NE36) or underpredicting (NE22) DMI in others.

Finally, IOFC increased from Can $\$ 14.3$ to Can $\$ 18.2$ / cow per day as the NE of clusters increased (Table 3). Phuong et al. (2013) mentioned that the cost of milk lost due to feeding low dietary $\mathrm{CP}$ is much greater than the cost of feeding high dietary protein. Our results showed the opposite, as increasing NE was related to enhanced economic benefits, which confirmed the observations reported by Powell et al. (2010).

\section{CONCLUSIONS}

By grouping the 100 Québec dairy herds based on their NE, we were able to identify differences in cow performance and feeding strategies between clusters. Among parameters related to animal performance, herds in clusters with the highest NE had lower DMI, measured over a 24 -h period, but greater milk yield than those in the less efficient clusters. It seems, therefore, that DMI has a major effect on NE, adding to the interest of studying residual feed intake in dairy cows. Among dietary factors, lower CP concentrations and greater dietary NFC and starch (mainly from corn silage) were observed in more efficient clusters compared with clusters with lower NE. Although MUN did not reflect small differences in $\mathrm{NE}$ and dietary $\mathrm{CP}$, it captured the difference between the herds with the lowest NE and highest dietary $\mathrm{CP}$ and the herds with the highest NE and lowest dietary CP. Decreasing RDP and MP balances relative to predicted requirements was also associated with greater NE. These observations suggest that it is possible to achieve greater $\mathrm{NE}$ by avoiding excess RDP in combination with increasing the supply of rumen available energy sources in the diet. Finally, it is suggested that increasing NE is a way to reduce N pollution from lactating herds. This study, conducted in commercial settings in eastern Canada, shows that it is possible to improve NE of cows while obtaining greater IOFC in dairy operations.

\section{ACKNOWLEDGMENTS}

This study was funded through the Programme de recherche en partenariat sur la préservation et l'amélioration de la valeur nutritive des aliments en lien avec la santé Fondation des maladies du cœur et de l'AVC et Visez santé, Ministère de l'Agriculture, des Pêcheries et de l'Alimentation, Ministère de la Santé et des Services sociaux, Fonds de recherche du Québec-Nature et technologies et le Fonds de recherche du 
Québe-Santé. It was also funded through the Industrial Research Chair program of the Natural Sciences and Engineering Research Council of Canada (Ottawa, ON, Canada), with industry contributions from the Dairy Farmers of Canada (Ottawa, ON, Canada), Novalait Inc. (Québec, QC, Canada), Les Producteurs de Lait du Québec (Longueuil, QC, Canada), and the Ministère de l'Agriculture, des Pêcheries et de l'Alimentation du Québec (Québec, QC, Canada). The authors thank Christiane Girard at Agriculture and Agri-Food Canada (Sherbrooke, QC, Canada) for her participation in this project and Roxane Robichaud, Valérie Audet, and Isabelle Duval at Université Laval (Québec, QC, Canada) for help with data collection and sample analysis. The authors also thank the farmers who participated in this study by allowing access to their farms and all the required information and samples.

\section{REFERENCES}

Aguilar, M., M. D. Hanigan, H. A. Tucker, B. L. Jones, S. K. Garbade, M. L. McGilliard, C. C. Stallings, K. F. Knowlton, and R. E. James. 2012. Cow and herd variation in milk urea nitrogen concentrations in lactating dairy cattle. J. Dairy Sci. 95:7261-7268. https://doi.org/10.3168/jds.2012-5582.

Allen, M. S. 2000. Effects of diet on short-term regulation of feed intake by lactating dairy cattle. J. Dairy Sci. 83:1598-1624. https:// doi.org/10.3168/jds.S0022-0302(00)75030-2.

Ankom. 2009. Technology method Am 5-04. Rapid Determination of Oil/Fat Utilizing High Temperature Solvent Extraction. Accessed May 28, 2017. https://www.ankom.com/sites/default/files/ document-files/CrudeFat_0504_013009.pdf.

Ankom. 2017a. Technology method 6. NDF in feeds-filter bag technique for A200. Accessed May 28, 2017. https://www.ankom.com/ sites/default/files/document-files/Method_6_NDF_A200.pdf.

Ankom. 2017b. Technology method 12. ADF in feeds - filter bag technique. Accessed May 28, 2017. https://www.ankom.com/ sites/default/files/document-files/Method_12_ADF_A2000.pdf.

Ankom. 2017c. Technology method 13. NDF in feeds-filter bag technique. Accessed May 28, 2017. https://www.ankom.com/sites/default/files/document-files/Method_13_NDF_A2000.pdf.

AOAC International. 2000. Official Methods of Analysis. 17th ed. AOAC International, Arlington, VA.

AOAC International. 2005. Official Methods of Analysis. 18th ed. AOAC International, Arlington, VA.

AOCS (American Oil Chemists' Society). 2008. Official Methods and Recommended Practices of the American Oil Chemists' Society. 5th ed. Am. Oil Chem. Soc., Urbana, IL.

Arndt, C., J. M. Powell, M. J. Aguerre, and M. A. Wattiaux. 2015 Performance, digestion, nitrogen balance, and emission of manure ammonia, enteric methane, and carbon dioxide in lactating cows fed diets with varying alfalfa silage-to-corn silage ratios. J. Dairy Sci. 98:418-430. https://doi.org/10.3168/jds.2014-8298.

Arriaga, H., M. Pinto, S. Calsamiglia, and P. Merino. 2009. Nutritional and management strategies on nitrogen and phosphorus use efficiency of lactating dairy cattle on commercial farms: An environmental perspective. J. Dairy Sci. 92:204-215. https://doi. org/10.3168/jds.2008-1304.

Bach, A., S. Calsamiglia, and M. D. Stern. 2005. Nitrogen metabolism in the rumen. J. Dairy Sci. 88(E-Suppl.):E9-E21. https://doi. org/10.3168/jds.S0022-0302(05)73133-7.

Borcard, D., G. Francois, and P. Legendre. 2011. Numerical Ecology with R. Springer, New York, NY.

Brito, A. F., and G. A. Broderick. 2006. Effect of varying dietary ratios of alfalfa silage to corn silage on production and nitrogen utili- zation in lactating dairy cows. J. Dairy Sci. 89:3924-3938. https:// doi.org/10.3168/jds.S0022-0302(06)72435-3.

Broderick, G. A. 1995. Performance of lactating dairy cows fed either alfalfa silage or alfalfa hay as the sole forage. J. Dairy Sci. 78:320 329. https://doi.org/10.3168/jds.S0022-0302(95)76640-1.

Broderick, G. A. 2003. Effects of varying dietary protein and energy levels on the production of lactating dairy cows. J. Dairy Sci. 86:1370-1381. https://doi.org/10.3168/jds.S0022-0302(03)73721-

Broderick, G. A., and M. K. Clayton. 1997. A statistical evaluation of animal and nutritional factors influencing concentrations of milk urea nitrogen. J. Dairy Sci. 80:2964-2971. https://doi. org/10.3168/jds.S0022-0302(97)76262-3.

Bussink, D. W., and O. Oenema. 1998. Ammonia volatilization from dairy farming systems in temperate areas: A review. Nutr. Cycl. Agroecosys. 51:19-33. https://doi.org/10.1023/a:1009747109538.

Calsamiglia, S., A. Ferret, C. K. Reynolds, N. B. Kristensen, and A. M. van Vuuren. 2010. Strategies for optimizing nitrogen use by ruminants. Animal 4:1184-1196. https://doi.org/10.1017/ S1751731110000911.

Canadian Council on Animal Care. 1993. Guide to the Care and Use of Experimental Animals. 2nd ed. Vol. 1. E. D. Rolfert, B. M. Cross, and A. A. McWilliam, ed. Can. Counc. Anim. Care, Ottawa, Ontario, Canada.

Chase, L. E. 2007. Can we feed less starch to our cows? Pages 213-220 in Proc. Cornell Nutr. Conf. for Feed Manuf., Syracuse, NY. Cornell University, Ithaca, NY.

Colmenero, J. J., and G. A. Broderick. 2006a. Effect of amount and ruminal degradability of soybean meal protein on performance of lactating dairy cows. J. Dairy Sci. 89:1635-1643. https://doi org/10.3168/jds.S0022-0302(06)72230-5.

Colmenero, J. J., and G. A. Broderick. 2006b. Effect of dietary crude protein concentration on milk production and nitrogen utilization in lactating dairy cows. J. Dairy Sci. 89:1704-1712. https://doi. org/10.3168/jds.S0022-0302(06)72238-X.

Colucci, P. E., L. E. Chase, and P. J. Van Soest. 1982. Feed intake, apparent diet digestibility, and rate of particulate passage in dairy cattle. J. Dairy Sci. 65:1445-1456. https://doi.org/10.3168/jds. S0022-0302(82)82367-9.

Connor, E. E., J. L. Hutchison, H. D. Norman, K. M. Olson, C. P. Van Tassell, J. M. Leith, and R. L. Baldwin. 2013. Use of residual feed intake in Holsteins during early lactation shows potential to improve feed efficiency through genetic selection. J. Anim. Sci. 91:3978-3988. https://doi.org/10.2527/jas.2012-5977.

Dann, H. M., H. A. Tucker, K. W. Cotanch, P. D. Krawczel, C. S Mooney, R. J. Grant, and T. Eguchi. 2014. Evaluation of lower-starch diets for lactating Holstein dairy cows. J. Dairy Sci. 97:7151-7161. https://doi.org/10.3168/jds.2014-8341.

de Roos, A. P. W., H. van den Bijgaart, J. Hørlyk, and G. de Jong. 2007. Screening for subclinical ketosis in dairy cattle by Fourier transform infrared spectrometry. J. Dairy Sci. 90:1761-1766. https://doi.org/10.3168/jds.2006-203.

Denis-Robichaud, J., J. Dubuc, D. Lefebvre, and L. DesCôteaux. 2014. Accuracy of milk ketone bodies from flow-injection analysis for the diagnosis of hyperketonemia in dairy cows. J. Dairy Sci. 97:33643370. https://doi.org/10.3168/jds.2013-6744.

DePeters, E. J., and J. D. Ferguson. 1992. Nonprotein nitrogen and protein distribution in the milk of cows. J. Dairy Sci. 75:3192 3209. https://doi.org/10.3168/jds.S0022-0302(92)78085-0.

Dijkstra, J., O. Oenema, and A. Bannink. 2011. Dietary strategies to reducing $\mathrm{N}$ excretion from cattle: Implications for methane emissions. Curr. Opin. Environ. Sustain. 3:414-422. https://doi. org $/ 10.1016 / j . c o s u s t .2011 .07 .008$.

Edouard, N., M. Hassouna, P. Robin, and P. Faverdin. 2016. Low degradable protein supply to increase nitrogen efficiency in lactating dairy cows and reduce environmental impacts at barn level Animal 10:212-220. https://doi.org/10.1017/S1751731115002050.

Gaines, W. L. 1928. The energy basis of measuring milk yield in dairy cows. Tech. bull. no. 308. Agric. Exp. Sta., Champaign, IL.

Gourley, C. J. P., S. R. Aarons, and J. M. Powell. 2012. Nitrogen use efficiency and manure management practices in contrasting dairy 
production systems. Agric. Ecosyst. Environ. 147:73-81. https:// doi.org/10.1016/j.agee.2011.05.011.

Hart, K. D., B. W. McBride, T. F. Duffield, and T. J. DeVries. 2014 Effect of frequency of feed delivery on the behavior and productivity of lactating dairy cows. J. Dairy Sci. 97:1713-1724. https://doi. org/10.3168/jds.2013-7504.

Hristov, A. N., M. Hanigan, A. Cole, R. Todd, T. A. McAllister, P. M. Ndegwa, and A. Rotz. 2011. Review: Ammonia emissions from dairy farms and beef feedlots. Can. J. Anim. Sci. 91:1-35. https:// doi.org/10.4141/CJAS10034

Hristov, A. N., W. J. Price, and B. Shafii. 2004. A meta-analysis examining the relationship among dietary factors, dry matter intake, and milk and milk protein yield in dairy cows. J. Dairy Sci. 87:2184-2196. https://doi.org/10.3168/jds.S0022-0302(04)70039-

Hristov, A. N., and J. K. Ropp. 2003. Effect of dietary carbohydrate composition and availability on utilization of ruminal ammonia nitrogen for milk protein synthesis in dairy cows. J. Dairy Sci 86:2416-2427. https://doi.org/10.3168/jds.S0022-0302(03)73836-

Huhtanen, P., E. H. Cabezas-Garcia, S. J. Krizsan, and K. J. Shingfield. 2015. Evaluation of between-cow variation in milk urea and rumen ammonia nitrogen concentrations and the association with nitrogen utilization and diet digestibility in lactating cows. J. Dairy Sci. 98:3182-3196. https://doi.org/10.3168/jds.2014-8215.

Huhtanen, P., and A. N. Hristov. 2009. A meta-analysis of the effects of dietary protein concentration and degradability on milk protein yield and milk N efficiency in dairy cows. J. Dairy Sci. 92:32223232. https://doi.org/10.3168/jds.2008-1352.

Jonker, J. S., R. A. Kohn, and J. High. 2002a. Dairy herd management practices that impact nitrogen utilization efficiency. J. Dairy Sci. 85:1218-1226. https://doi.org/10.3168/jds.S0022-0302(02)741854

Jonker, J. S., R. A. Kohn, and J. High. 2002b. Use of milk urea nitrogen to improve dairy cow diets. J. Dairy Sci. 85:939-946. https:// doi.org/10.3168/jds.S0022-0302(02)74152-0.

Kendall, P. E., C. B. Tucker, D. E. Dalley, D. A. Clark, and J. R. Webster. 2008. Milking frequency affects the circadian body temperature rhythm in dairy cows. Livest. Sci. 117:130-138. https:// doi.org/10.1016/j.livsci.2007.12.009.

Les Producteurs de Grains du Québec. 2016. Marché local. Accessed Feb. 8, 2016. http://www.pgq.ca/mise-en-marche/marche-local/.

Les Producteurs de Lait du Québec. 2016. Some figures. Accessed Feb. 12, 2016. http://lait.org/en/the-milk-economy/some-figures/.

Li, B., W. F. Fikse, J. Lassen, M. H. Lidauer, P. Løvendahl, P. Mäntysaari, and B. Berglund. 2016. Genetic parameters for dry matter intake in primiparous Holstein, Nordic Red, and Jersey cows in the first half of lactation. J. Dairy Sci. 99:7232-7239. https://doi. org /10.3168/jds.2015-10669.

Nousiainen, J., K. J. Shingfield, and P. Huhtanen. 2004. Evaluation of milk urea nitrogen as a diagnostic of protein feeding. J. Dairy Sci 87:386-398. https://doi.org/10.3168/jds.S0022-0302(04)73178-1.

NRC. 2001. Nutrient Requirements of Dairy Cattle. 7th rev. ed. Natl. Acad. Press, Washington, DC

Phuong, H. N., N. C. Friggens, I. J. M. de Boer, and P. Schmidely. 2013. Factors affecting energy and nitrogen efficiency of dairy cows: A meta-analysis. J. Dairy Sci. 96:7245-7259. https://doi. org $/ 10.3168 /$ jds.2013-6977.

Powell, J. M., C. J. P. Gourley, C. A. Rotz, and D. M. Weaver. 2010. Nitrogen use efficiency: A potential performance indicator and policy tool for dairy farms. Environ. Sci. Policy 13:217-228. https:// doi.org/10.1016/j.envsci.2010.03.007.

Powell, J. M., D. B. Jackson-Smith, D. F. McCrory, H. Saam, and M. Mariola. 2006. Validation of feed and manure data collected on Wisconsin dairy farms. J. Dairy Sci. 89:2268-2278. https://doi. org/10.3168/jds.S0022-0302(06)72298-6.

Roe, M. B., C. J. Sniffen, and L. E. Chase. 1990. Techniques for measuring protein fractions in feedstuffs. Pages 81-88 in Proc. Cornell Nutr. Conf. for Feed. Manuf., Syracuse, NY. Cornell University, Ithaca, NY.

Rotz, C. A. 2004. Management to reduce nitrogen losses in animal production. J. Anim. Sci. 82(E-Suppl.):E119-E137.

SAS Institute Inc. 2011. SAS/Stat 9.3 User's Guide. SAS Inst. Inc. Cary, NC.

Sova, A. D., S. J. LeBlanc, B. W. McBride, and T. J. DeVries. 2013 Associations between herd-level feeding management practices, feed sorting, and milk production in freestall dairy farms. J. Dairy Sci. 96:4759-4770. https://doi.org/10.3168/jds.2013-6679.

Valacta. 2015. L'évolution de la production laitière québécoise 2014. Accessed Jun. 14, 2016. http://www.valacta.com/FR/ Nos-publications/Documents/ÉVOLUTION\%20LAITIERE/ Évolution\%202014_FINAL.pdf.

Valacta. 2016. L'évolution de la production laitière québécoise 2015. Accessed Jun. 14, 2016. http://www.valacta.com/FR/Nospublications/Documents/EL2015 FINAL2.pdf.

Vallimont, J. E., C. D. Dechow, J. M. Daubert, M. W. Dekleva, J. W. Blum, C. M. Barlieb, W. Liu, G. A. Varga, A. J. Heinrichs, and C. R. Baumrucker. 2010. Genetic parameters of feed intake, production, body weight, body condition score, and selected type traits of Holstein cows in commercial tie-stall barns. J. Dairy Sci. 93:4892-4901. https://doi.org/10.3168/jds.2010-3189.

Van Soest, P. J., J. B. Robertson, and B. A. Lewis. 1991. Methods for dietary fiber, neutral detergent fiber, and nonstarch polysaccharides in relation to animal nutrition. J. Dairy Sci. 74:3583-3597. https://doi.org/10.3168/jds.S0022-0302(91)78551-2.

Veerkamp, R. F., and S. Brotherstone. 1997. Genetic correlations between linear type traits, food intake, live weight and condition score in Holstein-Friesian dairy cattle. Anim. Sci. 64:385-392. https://doi.org/10.1017/S1357729800015976.

Wattiaux, M. A., and P. M. Crump. 2014. Exploring milk urea-N excretion as a nutritional and environmental management tool for the dairy industry. J. Anim. Sci. 92(E-Suppl. 2):350. (Abstr.)

Wattiaux, M. A., E. V. Nordheim, and P. Crump. 2005. Statistical evaluation of factors and interactions affecting dairy herd improvement milk urea nitrogen in commercial Midwest dairy herds. J. Dairy Sci. 88:3020-3035. https://doi.org/10.3168/jds.S00220302(05) 72982-9.

Yan, T., C. S. Mayne, D. C. Patterson, and R. E. Agnew. 2009. Prediction of body weight and empty body composition using body size measurements in lactating dairy cows. Livest. Sci. 124:233-241. https://doi.org/10.1016/j.livsci.2009.02.003. 